\title{
The autobiographical you: letters in the gendered politics of the labour movement
}

\author{
Maria Tamboukou, Centre for Narrative Research, UEL
}

\begin{abstract}
In this article, I consider the importance of epistolary narratives in the interface of autobiography and politics. In doing this, I read the letters of Fannia Mary Cohn, a Jewish immigrant worker, trade union activist and ardent labour organizer in the garment industry in the USA in the first half of the twentieth century. Cohn was a prolific writer and political activist and left a rich body of labour literature, but never wrote an autobiography or a diary or journal. It is in her letters to her comrades and friends in the labour movement that short autobiographical stories erupt and it is on such stories across her correspondence that this article focuses. The analysis is informed by Hannah Arendt's theorization of narratives in their interrelation with politics and history. Drawing on a rich body of feminist literature around the relational self, what I argue is that an Arendtian reading of epistolary narratives is a useful analytical tool in understanding gendered politics in the diverse histories of the labour movement.
\end{abstract}

Keywords: Arendt; Cohn; epistolary narratives; history; labour movement; politics; women workers

July 28, 1937

\section{Dear Friend,}

I was deeply impressed by your letter. To say that I am grateful to you for it would not express my feelings.

Two prominent persons, a man and a woman, who have distinguished themselves in the world of literature and art insisted that I give them material which they wanted to use in preparation of a sketch of my life and work. I flatly refused to do so. I will give you the same answer. I am not in a position now to provide this material.

[...] The work of enlightening the masses, of helping them to influence public opinion in our own organization and the labor movement is so imperative, that in comparison with this everything else seems insignificant [... ] I am kept occupied and I do enjoy my work. I try to get the best out of life and this keeps me busy enough.

Yes, I can back all this with many letters that I keep in a safe. Some day you will have access to them, but not now.

Now about Professor Beard's article which you read in the library. Professor Beard asked me for a personal statement, for documents and letters. I did not give him this as I did not want 
him to write a biographical sketch of me at this time. Whatever he did it was done on his own account $[\ldots]$

One more thing I want to leave you with. As you know I was never self-centered. I always pitied people who considered themselves the center of everything. They are unhappy. [...]

I wish I could come to the middle west and have a good chat with you but I cannot do this just now $[\ldots]$

Do let me hear from you whenever the spirit moves you. Contact with understanding friends is a pleasure that cannot be expressed in words $[\ldots]^{1}$

On 28 July 1937 Fannia Mary Cohn, a labour organizer, who served the Education Department of the International Ladies' Garment Workers' Union (ILGWU) between 1918 and 1962 and became one of its few women vice presidents, wrote a letter to a friend apparently declining a request to give them biographical information about her life. As the letter reveals, it was not the first time that she had been asked to give an account of her life; but she had turned down all such requests from a number of eminent scholars, including the historian Charles A. Beard, who was also a very good friend of hers throughout her life. Cohn's decision to keep her life to herself had nothing to do with her feelings towards her friends. She was on the contrary deeply appreciative of the value of friendship, 'a pleasure beyond words' as she put it in her above-mentioned letter. Thus, although refusing to give an account of herself, she promised her friend that her letters, which she kept in a safe, would be available in the future.

It was therefore thanks to Cohn's decision to create an archive of her life-long involvement in the US labour movement that her papers have been preserved and it is on the archive, Fannia M. Cohn's Papers, 1914-1962 (MssCol 588), housed in the New York Public Library, that this article draws on. ${ }^{2}$ Given that Cohn was not interested in herself, but in the struggles of the labour movement we can therefore understand why a woman who was such a prolific writer and left a rich corpus of labour literature did not write an autobiography or kept a personal journal or diary. Indeed, she was very careful in enfolding her life as a secret. As she wrote to her friend Emma many years later: 'my life story I did not reveal to anyone. I kept it to myself as I wanted to avoid a sensational impression'. ${ }^{3}$

Cohn's story was indeed sensational: she came from a well-off Jewish family, who lived in Kletzk, a town near Minsk in the Russian Pale, but from a very early age she joined the forces of the Socialist Revolutionary Party. Her involvement in a radical underground political organization was an effect of the untenable situation that many well-educated Jews in Eastern Europe had found themselves in at the dawn of the twentieth century. Cohn became politically active in the aftermath of the 1880 s murderous pogroms, encouraged by the Russian government's oppressive policies. But as Ricki Cohen has aptly observed, Cohn's choice to join 'a terrorist organization, which assassinated high Russian officials', but whose populist trends were in effect anti-Semitic, was indeed 'peculiar' (1976, p. 6). Contradictions and riddles in Cohn's political choices notwithstanding, she was determined to fight for change, but she eventually followed the route of emigration when in 1904 her brother almost died in a pogrom, as her abovementioned letter reveals. Despite her decision to leave Russia, however, political activism coloured her life choices and political orientations throughout her life. As she wrote to her friend Edward Lindeman in 1933:

Russia was the country in which I first saw the light of day, where I spent part of the young years of my life, and where I imbibed and first participated in the revolutionary spirit. These experiences influenced my whole life. When I arrived to the United States it led me into the Labor movement. ${ }^{4}$ 
On departing for the USA, Cohn gave one promise to her family: 'I would continue my studies in the "New World" as my mother wanted her children to be no less than professors', she wrote to Selig Perlman, after having admitted that 'I was brought up by my mother on books'. But on arriving in New York, Cohn's life plans once again changed radically, as she was too proud to accept financial assistance from her rich extended family: 'When I arrived in New York, my cousin's husband suggested that I continue my education and he would finance it. I came from a very proud family, Rosofskys, and from a revolutionary background. I therefore proudly refused this offer' ${ }^{6}$ Cohn worked for some time to support herself, but while she was in the process of preparing for the College of Pharmacy, the unpredictability of life took her to other directions:

It was the Triangle Fire that decided my life's course. This tragedy influenced then my decision to join the labor movement. I faintly remember joining the protest demonstration on the East Side against this tragedy, but I cannot recollect the streets where we marched. My brother and sister advised me to continue my education and afterwards enter the labor movement. I rejected this because I was convinced then that to voice the 'grievances', the hopes and aspirations of the workers, one must share in their experience. I then joined Local 41, I.L.G.W.U. and went to work in a shop and kept my story to myself. ${ }^{7}$

The Triangle Shirtwaist Company Fire, at the heart of Greenwich village in Manhattan New York, is one of the most tragic events in American Labour History: 146 young women garment workers died on 25 March 1911 while trying to escape the burning building within which they were locked (see Stein, 1962). This horrible event not only led to a series of changes in labour legislation and occupational safety standards but also marked the rise of women's active involvement in the labour histories of the twentieth century. Cohn's epistolary account of how this event shaped her decision to dedicate her life to the labour movement is an exemplary moment of the long-lasting impact that the Triangle Fire had upon the lives of many women trade unionists. This is what Pauline Newman (1887-1986), who was another significant figure in the ILGWU history, wrote to her friend Rose Schneiderman (1882-1972) on the aftermath of the disaster:

I suppose you are still waiting for the letter of which I spoke to you in my card of last week yet. I could not write, I could not do anything for the last two or three weeks, the Triangle tragedy had a terrible affect upon me. ${ }^{8}$

Having marked the lives of many women workers and labour organizers in the garment industry and beyond, the Triangle Fire also became a historical event in the agonistic politics of the labour movement in the USA, not only through the stories that were written and told about it, but also through an assemblage of mnemonic practices that women tradeunionists like Cohn, organized over the years. Indeed, Cohn's unpublished papers include lectures and speeches that she gave on the anniversary of the event, testimonies, as well as newspaper clippings about the acquittal of the Triangle Fire bosses:

[... ] I heard somebody cry 'Fire'. I left everything and ran for the Washington Place side. The door was locked and immediately there was a great jam of girls before it [... The fire had started on our floor, and quick as I had been in getting to the Washington Place door, the flames were already blazing fiercely and spreading fast. If we couldn't get out, we would all be roasted alive. The locked door that blocked us was half of wood; the upper half was thick glass. Some girls were screaming, some were beating the door with their fists, some were trying to tear it open. Someone broke out the glass part of the door with something hard and heavy - I suppose the head of a machine - and I climbed or was pulled through the broken glass and ran downstairs to the sixth floor, where someone took me down to the street $[\ldots]$ I got out to the street and watched the upper floors burning, and the girls hanging by their hands and then dropping as the fire reached up to them. There they were dead on the sidewalk. It was an awful, awful sight. ${ }^{9}$ 
The Triangle Fire was not just an event that erupted in Cohn's life and irrevocably changed her future plans, it was also the moment when she firmly decided 'to keep my story to myself'; perhaps she felt that the immensity of such life events absorbed any individual little tragedy or adventure like hers. Indeed, as her letter in the beginning of this article boldly reveals, Cohn considered herself as part of the labour movement, defying any self-centred practices as vectors of unhappiness. But although Cohn wanted her life to remain a secret, she would nevertheless often quote Beard's important statement that her life story transcends the personal and becomes interwoven in the writing of a seemingly alternative American history, a kind of labour epic: 'in his essay on the Workers' Educational Bureau [Beard] refers to me in these terms, and I quote "of her life and labor an American epic, can be written" [... $]^{10}$ In Cohn's perception then, Beard's authorial presence in the history of the American labour movement had validated her otherwise imperceptible life.

As an influential American historian and political scientist, Beard had a life-long interest in the history of the labour movement and was actively involved in the movement for workers' education, which is how he got to know and respect Cohn's work. ${ }^{11}$ Her papers include a series of letters in a line of correspondence that went throughout her life till Beard's death in 1948:

Without in any way depreciating the regular function of the trade union, I feel that educational work is of equal importance with all other activities [...] If the middle classes can spend millions on education, surely labor ought to find it worth while to spend hundreds. ${ }^{12}$

Beard wrote the letter above to the ILGWU educational committee on 26 July 1922 apologizing for his absence from the committee meeting, while openly supporting Cohn's plea to the union for financial support of the education department - a constant struggle year after year during her time of office. In a letter written to Cohn on Labor Day in 1945, Beard would recall 'that those of us who labored years ago to strengthen the workers' education movement know that we had many toilsome predecessors and had many helpers whose names are unknown [since] such is the nature of History in the making,. ${ }^{13}$ Beard would further reflect on the ideas that underpinned their struggle for workers' education, including their efforts to avoid 'dogmas on the labor movement and seek to make the education programme flexible - so as to allow for changing times'. ${ }^{14}$

Cohn's life-long correspondence with Beard is part of an extensive body of letters that Cohn sent and received from friends, comrades, educationalists and intellectuals that were involved in the labour movement in general and workers' education in particular. Apart from Beard, her correspondents include amongst others, the philosopher John Dewy, the journalist and labour activist Arthur Gleason, the civil rights activist Roger Baldwin, important trade unionists from all over the USA, the UK and Europe and last but not least her two life-long women friends, Evelyn Preston and Theresa Wolfson: 'I am a great believer in friendship, ${ }^{15}$ Cohn wrote to Preston on 2 January 1924, further elaborating on why friendship held such an important role in her life:

I never could over-estimate its value provided it is based on real understanding and confidence. Every person is eager to have a human being close to him. We cannot share with everyone around us some of our innermost feelings. And nothing is so helpful to deepening our minds and clarifying our thoughts as exchange of views with our friends [...] We can get the best out of our friends if we can make an effort. ${ }^{16}$

In thus following Cohn's letters, I had the chance to excavate different versions of her persona as they unfold in the seriality of her correspondence. In doing this, I was mindful of the discursive constraints within which these letters have to be read: it was Cohn herself 
who had selected them as part of her legacy and therefore these letters are read as an assemblage of autobiographical fragments, as effects of dominant discourses and practices, but also as counter discourses and narratives, what I discuss later on in the article as 'political autobiographics'. ${ }^{17}$ Thus, although Cohn never published an autobiography, she was very strategic in ensuring that her contribution to the history of the US labour movement in general and workers' education in particular would be recorded. As Ricki Cohen has pointed out, Fannia Cohn is 'the only woman vice-president of a predominantly female union who has bequeathed her papers to a major library' $(1976$, p. 1). Of course, this comes as no surprise, since Cohn was very conscious that if she did not do it, nobody would. The fact that her body 'was discovered in her apartment' (Cohen, 1976, p. 250) on 24 December 1962, only tragically shows that she was right to have taken care of her memories well before her death. This is after all the fate of many single women, whose memory gets lost because there is nobody to enact mnemonic and commemoration practices after they die. In becoming the creator of her own archive, Cohn consciously preserved the letters to her friends wherein she gave accounts of herself, thus offering her correspondents and consequently her 'external readers' (Altman, 1982), some rare, unique and carefully edited autobiographical moments. But why did she choose letters to tell her life story and how can her letters be analysed as autobiographical documents? This is what I discuss in the next section.

\section{Letters as autobiographical narratives: an Arendtian reading}

In looking at Cohn's epistolary moments, I draw on Hannah Arendt's take of narratives (1998) as traces of the historicity of the human condition, women's involvement in the turbulent histories of the labour movement in the first half of the twentieth century in the case of this article. A central understanding in Arendt is that stories ground abstractions, flesh out ideas and thus create a milieu where thought can emerge from the actuality of the recounted event:

I have always believed that, no matter how abstract our theories may sound or how consistent our arguments appear, there are incidents and stories behind them, which, at least for ourselves, contain as in a nutshell the full meaning of whatever we have to say. Thought itself - to the extent that is more than a technical logical operation with electronic machines may be better equipped to perform than the human brain - arises out of the actuality of incident, and incidents of living experience must remain its guideposts by which it takes its bearing if it is not to lose itself. ${ }^{18}$

What is particularly interesting in the last sentence of this extract that comes from the paper 'Action and the Pursuit of Happiness' that Arendt delivered at the Annual meeting of the American Political Science Association in New York, in September 1960 is the link between the cognitive and political aspects of storytelling: 'incidents of living experience must remain the guideposts of thought' Arendt argues, otherwise thought is in danger of 'losing itself'. By further referring to 'incidents of living experience', it is not just stories but life histories or biographies that Arendt highlights as important in how meaning emerges, ideas are shared and action is reactivated. For Arendt, Kristeva notes, story making fulfills life as it contributes to the pursuit of both meaning and action: 'the revelatory character of action as well as the ability to produce stories and become historical, which together form the very source from which meaningfulness springs into and illuminates human existence' (Arendt, 1998, p. 324).

Arendt's understanding of the biographical discourse is equally unique however. Life histories generate meaning, but this meaning is only accessible to the tellers and listeners 
of the stories, not to their protagonists. This is because human beings live fragmented lives whose meaning always evades them; they thus need others to tell their stories and create archives for historical understanding. Moreover, political actors can never control their actions as the latter are entangled in the web of human relations and are therefore conditioned by 'innumerable conflicting wills and intentions' (Arendt, 1998, p. 184). As a consequence, it falls to the historian, the biographer or the storyteller, who is external to the sphere of action to seek for meaning by telling or writing a story about the actor, her words and her deeds. It is this idea of a life lived as action that can be narrativized and shared by others who did not necessarily participate in the narrated action that makes the Arendtian conceptualization of narratives so compelling and so relevant to her overall work as a political philosopher.

Indeed, Arendt' philosophical take on biography suggests that 'we need to find a discourse, a lexis, that can answer the question "Who are you?" [...] Narrative will fulfi this role, the invented story that accompanies history' (Kristeva, 2001, p. 15). What is exactly the relationship between the 'invented story' and history? In Arendt's thought, Kristeva notes, there is a discrepancy between the actor and what constitutes a heroic action. As already discussed earlier, actors make history only if their action is recorded and becomes memorable and this memorialization is the role of narratives: 'One immortalizes one's self by becoming a "who" that acts within political space, thus giving rise only to a memorable narrative.' (p. 19) How is this memory constituted? 'It is spectators who complete the story in question, and they do so through thought, thought that follows upon the act. This is a completion that takes place through evoked memory, without which there is nothing to tell.' (p. 16)

In this light, Kristeva further comments, life story and history are bound together in Arendt's philosophy in an Aristotelian mode that 'differs, in its originality, from both the formalist theories of narrativity and the theories of Paul Ricoeur.' (p. 15) Why is that? Arendt is not concerned with the narratologists' obsession on narrative coherence ${ }^{19}$ and she actually thinks that stories should reveal what sequence often covers: 'the story reveals the meaning of what otherwise would remain the unbearable sequence of sheer happenings' (Arendt, 1968, p. 104). Rather than following the imperative of the beginning, middle and end of the Aristotelian Poetics, Arendt's interest therefore lies with the importance of narrative agency and closure in Aristotle's Nicomachean Ethics. As Kristeva pithily notes in this philosophical text 'the art of narrative resides in the ability to condense the action into an exemplary moment, to extract it from the continuous flow of time, and reveal a who' (2001, p. 16). This interest in freezing the exemplary moment wherein human beings reveal themselves to the world through action and speech, also differs from Ricoeur's theories that focus on the interrelation between temporality and narrativity, ${ }^{20}$ the importance that he assigns to the plot in the formation of narrative identity and the way he dismisses the 'now' as concealing the 'true constitution of time' (Ricoeur, 1981, p. 166).

In highlighting the importance of stories in creating meaning, however, Arendt makes the distinction between revealing meaning and defining it. In doing so, she points to the impossibility of pinning down what stories are about or what subjects should be or do. 'It is true', she notes 'that storytelling reveals meaning without committing the error of defining it' (Arendt, 1968, p. 105). But the meaning of this story of course will always be negotiated by the audience, the community of memory that stories are addressed to, since as Sheldon Wolin has commented, for Arendt 'audience is a metaphor for the political community whose nature is to be a community of remembrance' (Wolin, 1977, p. 97). In this light, it is important to remember that closure refers here to the power of stories to reveal the meaning of actions and thus complete them; it does not refer to the closure of the story itself, the Aristotelian telos, the end of the plot. As Olivia Guaraldo has therefore 
suggested, 'history as a togetherness of stories' creates conditions of possibility for forgotten or marginalized stories to be re-enacted, and thus stories are instrumental in creating a vantage point from which to retrace other possible paths between our past, our present and our future (2001, p. 25).

But apart from revealing meaning about lives and political actors, storytelling for Arendt is 'a way of representing political reality by preserving the contingency and freedom that characterize the realm of the vita activa, Guaraldo has pithily remarked (2001, p. 4). Cohn's autobiographical letters to her friends constitute an excellent Arendtian paradigm of the power of stories in conveying the unexpected effects of life events, as well as the unpredictability of political action within the life of an individual and beyond. It is precisely in the unexpected possibilities of life as action that freedom resides for Arendt and in this light "freedom is not an abstract principle [but] the modality by which our human condition actualizes itself' (Guaraldo, 2001, p. 34).

Arendt's take on narratives is particularly relevant to Cohn's case. Cohn was an Arendtian political actor par excellence: her life was full of action, she had no time to write her story and indeed she was not interested in doing it. Cohn was too busy working for the labour movement and changing the world to have time for herself or her life story. But as already discussed, although Cohn did not seem to have either the desire or the time to write her life story, she was a voluminous letter-writer: it was through letters that she communicated not only with her friends, but also with a network of people involved in workers' education either as academics, teachers, trade unionists, policy-makers, politicians or journalists. As Margaretta Jolly has noted in her work with letters in contemporary feminism, 'letters are a staple of any political movement' $(2008$, p. 2) and this is particularly evident in Cohn's extensive correspondence with women and men actively involved in the labour movement. It was through her letters that Cohn would communicate across social, political and geographical boundaries. Her correspondence with the Workers' Education Association in the UK, for example shows how much she was influenced by the educational philosophy vision and approaches of the British experience. In the same line, she had a warm exchange of letters with Marion Philipps (1881-1932), editor of Labour Woman and Labour Party politician in the UK on a range of issues including the miners' strike in 1926 as well as about the idea of 'women's auxiliaries':

I am following up with great interest, your work among the labor. Unfortunately in our country, the important social force that wives of trade unionists can be to the labor movement is hardly appreciated; and they are entirely neglected. I have written five articles on the wives of trade unionists, which were reprinted in almost $30 \%$ of the labor press, and I was glad to hear that many leading men and women in the labor movement were impressed with the possibility of ladies' auxiliaries taking proper place in our movement. Of course, the word "ladies" is not mine. That is how they call themselves, but when I criticised it and suggested that they change it to 'women's' there was general approval ……...21

It is therefore in themes emerging from the narrativity of her correspondence, framed within real and discursive constraints of her epistolary self that my analytical interest has focused, drawing on Arendt's insights about the importance of analysing narrative moments. The Chicago strike that Cohn recounts in her following letter is such an exemplary Arendtian moment: a struggle that erupts in a local factory, but eventually becomes an event with a lasting impact on the history of trade unionism in the garment industry:

My family then insisted that I return to New York, but instead I went to work in the Herzog factory [...] Conditions there were terrible and I began to carry on an 'underground' campaign on 'my own hook'. [...] One day, we called a strike and the few thousand workers walked out. [...] It was a terrific struggle. The police were brutal. They almost arrested every 
striker on the picket line, including myself. It aroused the interest of the community. The strikers were joined on the picket by John Fitzatrick, Mother Jones, many other outstanding labor leaders, and the wives of liberal professors [...] When the strike was finally settled, a board of arbitration was established [...] I was appointed chief clerk [...] This was the beginning of local 100 in Chicago. ${ }^{22}$

Interestingly for an Arendtian reading, what Cohn highlights here is the importance of a new beginning. Beginning is indeed a crucial concept in Arendt's theoretical configuration of the human condition and further shapes Arendt's understanding of the political, an arena where new beginnings are always possible: 'the essence of all, and in particular of political action is to make a new beginning' (Arendt, 1994, p. 321).

In this context, the exemplary moment of the Chicago strike not only condenses revolutionary action and enacts a new beginning, but also reveals Cohn not just in terms of 'what' she is in the intersection of social axes of difference - a woman, an immigrant, a worker, a labour organizer - but most importantly in existential terms of 'who she is' in her unrepeatable uniqueness as an Arendtian political subject, conditioned but not determined by the socio-cultural and political milieu of her actuality and therefore free to act upon them. It is precisely in highlighting the importance of the moment that letters become so crucially analytics. Following Arendt's lead, letters in my analysis are taken as 'portraits of moments', a phrase that comes from Hannah Arendt's biography of Rahel Varnhagen, her second doctoral thesis: 'I want a letter to be the portrait of a moment: that in which it is written' (Varnhagen cited in Weissberg, 2000, p. 11).

But how does the analytics of letters as 'portraits of moments' work? This is what I discuss next, by considering what drawing on Gilmore (1994) I have called 'political autobiographics', a discursive regime, a matrix where narratives of truth, experience and political action are knitted together. What I want to highlight here is that rather than reading Cohn's letters at face value, I situate them within a complex network of discursive limitations, power relations and forces of desire that have created conditions of possibility for her epistolary narratives to emerge. The following extract where she gives her own account of a turbulent period in ILGWU is an exemplary moment of what I have called 'political autobiographics' at work:

In 1920 when the Communists were fighting our union and were set upon to destroy the Union Health Center and we had no funds to carry on the institutions, most of the people connected with the office left it including Pauline Newman, who went to Philadelphia to work for the women's Trade Union League. It was then Harry Wander and I who 'stuck' to it and assisted Gr George Price to save it. ${ }^{23}$

Cohn's reference to the communist crisis in ILGWU in her autobiographical letter to Emma is not accidental. The 1920s was indeed a critical period in the ILGWU history, as the union was torn apart by the internal differences and the communists' activities to take over the organization. Although supportive of revolutionary socialism since her youth, Cohn was against the idea of the labour movement being subordinated to the ideology and needs of any political organization and she believed that workers would eventually succeed in standing as an autonomous body. It was in this spirit that although opposed to the communists, she refused to bar them from the activities of the Educational Department since it was her firm conviction that all union members should have access to educational and cultural opportunities regardless of their political affiliation. Her conciliatory stance created a lot of tension with her colleagues and comrades in the union and she found herself being accused by both parts. This untenable position severely affected her health and created a lot of anxiety and concern: 'at such a time of intolerance and mutual distrust one is in danger of getting hardened and embittered. That I would never survive .. . ${ }^{, 24}$ she 
wrote to Evelyn Preston. Cohn was aware of how her position in the 1920s crisis had been misinterpreted and used against her in the union. In thus writing to Emma in 1953 about the ILGWU crisis, she was attempting to get the records straight and recover her position in the consciousness and memory of the younger union members. In thus giving an account of herself, Cohn was also actively rewriting herself in the histories of the labour movement.

A glimpse in a range of letters she wrote in 1923 at the heart of the ILGWU crisis as recounted here gives an idea of Cohn's polyvalent persona as unfolded through her correspondence. By selecting a range of themes that emerge just from one year of her letterwriting practices, what I want to suggest is that the epistolary form lends itself to the expression of the various forms that the self can take, particularly in relation to the addressee of the correspondence. In this light, Cohn's 1923 line of correspondence significantly starts with a letter she writes to John Frey, labour leader and editor of the Molder's journal, in appreciation of Arthur Gleason, whose death had profoundly saddened her: Gleason's life illuminates for Cohn the ideal figure of the intellectual within the labour movement:

Arthur Gleason was essentially a poet; he was dragged into social movements [... ] His gentle, artistic soul was always in search of expression, and this he found partly in his love for nature and in his interest in the labor movement. He was one of the very few intellectuals in America who had a real respect for the labor movement [ . . . It was always his belief that the leadership, spiritual, intellectual as well as economic, must emerge from within [...] He was one of the few who had a conception of what Workers' Education should be and its place in the American Labor Movement, and he urged that this movement be confined to the trade unions, and be directed by them and that the place of the intellectual in it be in an advisory capacity. ${ }^{25}$

This epistolary extract is an exemplar of Cohn's philosophical epistolary discourse and becomes part of a specific sub-genre within her correspondence: letters opening up space for reflection, remembering and imagination. But long and reflective letters such as the above-mentioned letter, were only part of her daily epistolary practices. Cohn's letters also reveal that she was practical and down to earth in organizational matters and it was through correspondence that much of her union work was done: 'I appreciate the fact that you realize how hard it is for us to "get across" health lectures for our members [ .. . ] those of us who are pioneers in this movement, must [.. . ] suffer inconveniences', ${ }^{26}$ she wrote to Dr Ian Galdson in February, in response to his letter about the difficulties of holding a lecture on occupational health to the ILGWU members. Cohn knew only too well how difficult it was to educate workers, but she was convinced that such difficulties were part of the struggle; indeed her correspondence shows how hard she worked to co-ordinate, sustain and support the educational and cultural activities of the union.

But apart from being a tireless organizer, Cohn was also a highly respected mentor: 'I think it is a well written, clear and exact statement ${ }^{27}$ she wrote in April to Emma Yanisky, a young woman who had sent her statement for her application to Brookwood College ${ }^{28}$ and was asking for feedback. This letter is also one of many she wrote throughout her life in support of young people's educational aspirations within the union and beyond. Her correspondence with Evelyn Preston ${ }^{29}$ carries traces of the importance of intellectual friendship in the tradition of the care of the self that Foucault (1988) has famously theorized. Her letter to Preston, written in May, beautifully illustrates Cohn's existential reflections as communicated to her friend:

The more serious-minded one is, the more earnest and honest one is with oneself, the more painful and difficult is it to make a choice and define one's place in this world of ours [...] Yes, friend, in it we observe the process of evolution [...] This evolution or change in a person just as in society is being accompanied by much spiritual and even physical suffering. 
But it is life. It is a part of the constant change of which history is so full. Even our body is constantly changing. We are ever breathing in new elements, discharging others, and breathing in again. There is constant displacement. ${ }^{30}$

But while being philosophical in her communication with close and dear friends, Cohn was also rigorous and sharp: her prescriptive and didactic letter to her colleague Spencer Miller about how the Worker's Educational Bureau should be represented is indicative of how clear her ideas about worker's education were: 'Instead of mentioning that "the WEB is promoting adult education" it should read that "the WEB is promoting adult workers' education." 31 Throughout her life and work, Cohn had steadily argued that adult education and workers' education should not be conflated and there are whole essays amongst her unpublished papers elaborating on this issue:
Workers' education is of course a part of adult education. When we discuss workers' education, however, we cannot consider it apart from the labor movement; we must think of it in terms of the workers' problems. The background of workers' education must be the labor movement [...] The workers' education movement is based on confidence in the masses and on the assumption that human nature is not static. Given the opportunity, the proper atmosphere, and an inspiring environment, human nature can be influenced. It has been further guided by the theory of modern concept that creative imagination and initiative can develop in varying degrees. ${ }^{32}$

It was in the context of such ideas about the importance of workers' education that Cohn refused to bar the communists from the educational activities of the union as already discussed earlier; while at the heart of the crisis she was preoccupied with organizing educational activities in Chicago and her November letter to Mary Carson at the Cloak Makers Union in Chicago offers detailed advice on what to do, including feedback about the level of the classes as well as the time slots chosen for the lectures. ${ }^{33}$ It is finally in relation to education that her correspondence of 1923 concludes with a letter written in December to Samuel Gompers, president of the American Federation of Labor, introducing her friend and comrade Theresa Wolfson, who 'was for several years educational supervisor of our Union Health Center and a member of our faculty [and] is now studying in Washington under Professor Hamilton [... ] working on her PhD [.. . ] thesis Women in Trade Union. ${ }^{, 34}$

In looking at some epistolary moments of a single year in Cohn's life-long correspondence, I have tried to show the various levels and sides of her social relations and agonistic politics as recorded in the archived letters mentioned earlier. Letters are of course important documents in revealing meaning about social practices and there is an interesting body of literature about the use of letters in sociological research (see Barton \& Hall, 2000). In this context, Cohn's letters inscribe the minutiae and micro-practices of women's involvement in the trade unions. But how much can letters 'reveal' about the autobiographical self? Do they have any privileged position as autobiographical documents? Although I have read Cohn's letters in a chronological order in an attempt to grasp temporal rhythms in her epistolary life, these letters are only fragments of lived experiences, they cannot be brought together by any Aristotelian coherence of beginning, middle and end and they absolutely lack the closure of canonical narratives. Indeed, these letters 'reveal' as much as they conceal: they leave traces of a woman in action, but they can never encompass any 'truth' about who Cohn 'really was' or how she felt. Then why are letters important in autobiographical research?

This question brings us back to the July 1937 letter that has initiated the discussion of this paper:

Look upon the situation the way I approach it - that is that groups seldom tolerate a person who has distinguished himself or herself in the field to which they are close to, unless that person has enough organized political power to sustain $i^{35}$ 
Autobiographical narration is interwoven with fierce power relations at play in Cohn's epistolary discourse: 'to appear means to stand before somebody else, and to depend upon that somebody in order to receive in return a confirmation of my existence', Guaraldo has pithily commented (2012, p. 99). Adriana Cavarero has further drawn our attention to the marginalization of the singular you: "the "you" is a term that is not at home in modern and contemporary developments of ethics and politics', she has written (2000, p. 90).

To the Arendtian line that human beings as unique existents live together and are constitutively exposed to each other, Cavarero adds the narratability of the self, its constitution by the desire of listening to her story being narrated; this narrative constitution however does not end up in pinning down the self within prescribed spaces, places, roles and identities. It does not produce an essence neither does it require one. Simply put, the narratable self can never be reducible to the content of her story. Narratability, Cavarero argues, is not about intelligibility, but about familiarity with the 'spontaneous narrating structure of memory' (Cavarero, 2000, p. 34). Lives and stories meet in a matrix of power and desire producing realities and saturating bodies. In this light, the self is grounded on a relational ontology and it is actually through the $I-y o u$ relationship as a process of storytelling that the self emerges.

Judith Butler is also interested in the dyadic encounter, in her configuration of what it means to give a narrative account of oneself (2005). We are compelled to give accounts of ourselves when we are summoned to do so, Butler writes: 'no account takes place outside the structure of address, even if the addressee remains implicit and unnamed, anonymous and unspecified' (2005, p. 36). But the story of the addressee always remains incomplete and opaque, Butler emphatically remarks, since it is constrained and limited by discourses, practices and norms that both pre-exist and condition any narrative of the I: "The narrative authority of the "I" must give way to the perspective and temporality of a set of norms that contest the singularity of my story' (2005, p. 37).

Either constitutive of narratable and relational subjectivity as in Cavarero, or always falling short of the task as in Butler, narration is a process where questions of the self are raised, thus opening up scenes for the enactment of ethical actions and responsibilities. As Butler aptly puts it, 'to take responsibility for oneself is to avow the limits of any selfunderstanding' (2005, p. 83). It is therefore on the level of the dyadic encounter, the I/you relationship enacted on the narrative scene of letter-writing that the autobiographical validity of analysing letters lies, within the overall political dimension of seeking for narrative meaning from an Arendtian perspective.

\section{Letters as political narratives}

In reading narratives from an Arendtian perspective, what I have argued in this article is that Cohn's letters to her friends and comrades in the labour movement create an interesting autobiographical archive of political action. Although fragmented, letters have been theorized as 'portraits of moments' that condense political action and thus reveal the existential uniqueness of their protagonists, within the plurality of the web of human relations they are entangled with.

Notwithstanding the discursive limitations within which narrative meaning emerges, Cohn's epistolary narratives offer a glimpse into the harsh minutiae of women workers' involvement in the history of the labour movement in the first half of the twentieth century, as well as moments of resistance and new beginnings. Cohn's epistolary autobiographical fragments thus emerge as traces of gendered memories of work and agonistic politics. 


\section{Acknowledgements}

I want to thank the British Academy (SG112079) for funding my archival research at the New York Public Library Manuscripts and Archives Division (NYPL). I am grateful to the NYPL archivists for facilitating my research there and for giving me permission to cite from Fannia Cohn's papers.

\section{Notes}

1. EC to 'dear friend', letter dated 28 July 1937, Correspondence, FCP/NYPL.

2. The archive comprises 15 boxes and it is divided in 9 series: I. Correspondence, 1914-1962 (boxes 1-5); II. Writings, ca.1920s to 1950s (boxes 6-8); III. International Ladies' Garment Workers' Union, 1920s to 1962 (boxes 9-12); IV. Workers' Education Bureau, 1920s to 1950s; V. Brookwood Labor College, 1924-1938 (box 12); VI. Youth Programs, 1932-1950s (box 13); VII. Edwin Markham Testimonial Committee Correspondence, 1928-1930 (box 13); VIII. Photographs, 1920s to 1962, and Oversize Items (box 14); IX. Other Groups (box 15). This article draws on the first three series, which are the largest in the collection (see also Tamboukou [2014a] for a discussion of series VIII, Cohn's collection of photographs). The collection is also available in 13 reels of microfilm, additionally housed at the Labor Management Documentation Center, Catherwood Library, Cornell University, Ithaca and at the Robert F. Wagner Labor Archives, Bobst Library, New York University.

3. FC to Emma, letter dated 8 May 1953, Correspondence, FCP/NYPL. Unfortunately there is no biographical information about Emma in the literature about and around Cohn.

4. FC to EG Lindeman, letter dated 7 February 1933, Correspondence, FCP/NYPL.

5. FC to Selig Perlman, letter dated 26 December 1951, Correspondence, FCP/NYPL.

6. FC to Emma, letter dated 8 May 1953, Correspondence, FCP/NYPL.

7. FC to Emma, letter dated 8 May 1953, Correspondence, FCP/NYPL.

8. PN to RS, letter dated 12 April 1911, RSP/TAM. Both Pauline Newman and Rose Schneiderman were important figures in the US labour history and feminist movement. I am grateful to the University of East London for funding my research with Rose Schneiderman's papers at the Tamiment Library in New York, in June-July 2011. Although both Newman and Schneiderman are included in my overall project of writing a genealogy of the seamstress (Tamboukou, 2013, $2014 a, b)$, I could not expand on them within the limitations of this article.

9. ILGWU documents, FCP/NYPL. This is the story of one girl who escaped, Rosey Safran. It appeared in the News-History magazine of the ILGWU on May 1950 and was then archived in Cohn's papers.

10. FC to Emma, letter dated 8 May 1953, Correspondence, FCP/NYPL.

11. See Ellen's (1983) intellectual biography for more details.

12. CB to ILGWU educational department, letter dated 26 July 1922, Correspondence, FCP/NYPL.

13. CB to FC, letter dated Labor day, 1945, Correspondence, FCP/NYPL.

14. CB to FC, letter dated Labor day, 1945, Correspondence, FCP/NYPL.

15. FC to EP, letter dated 2 January 1924, Correspondence, FCP/NYPL.

16. FC to EP, letter dated 2 January 1924, Correspondence, FCP/NYPL.

17. Elsewhere in my work (Tamboukou, 2011), I have also theorized letters as 'epistolary technologies of the self' drawing on Foucault's (1988) influential concept, but in this article the analysis focuses more on the role of letters in the gendered politics of the labour movement.

18. 'Action and the Pursuit of Happiness', lecture, American Political Science Association, New York, NY. - 1960 (Series: Speeches and Writings File, 1923-1975, n.d.), Hannah Arendt papers at the Library of Congress.

19. For a discussion of coherence in classical narratology, see Hyvärinen, Hydén, Saarenheimo, and Tamboukou (2010).

20. As Ricoeur notes on this interrelation: 'I take temporality to be the structure of existence that reaches language in narrativity and narrativity to be the language structure that has temporality as its ultimate referent' (1981, p. 165).

21. FC to Marion Phillips, letter dated 29 July 1927, Correspondence, FCP/NYPL.

22. FC to Emma, letter dated 8 May 1953, Correspondence, FCP/NYPL.

23. FC to Emma, letter dated 8 May 1953, Correspondence, FCP/NYPL.

24. FC to EP, letter dated 9 October [no year], Correspondence, FCP/NYPL. 
25. FC to JF, letter dated 8 January 1923, Correspondence, FCP/NYPL.

26. FC to IG, letter dated 14 February 1923 Correspondence, FCP/NYPL.

27. FC to EY, letter dated 8 April 1923, Correspondence, FCP/NYPL.

28. The establishment of Brookwood Labour College in 1921 was an important event in the history of workers' education in the USA. Cohn was very much involved in the founding and running of the college, from the beginning till its final closure in 1937 after a series of financial difficulties as well as a controversy over the politics of its head, A.J. Muste. Cohn's papers include an interesting body of documents and correspondence about Brookwood (FCP/NYPL). See also Howlett (1993).

29. Evelyn Preston was a wealthy and well-educated young woman with a passionate interest in the labour movement. She became very close to Cohn between 1922-1924 and funded many of her educational projects. For more discussion about Cohn's friendship with Preston see Tamboukou (2014b).

30. FC to EP, letter dated 3 May 1923, Correspondence, FCP/NYPL.

31. FC to SM, letter dated 24 July 1923 , Correspondence, FCP/NYPL.

32. 'Workers' education today and tomorrow', unpublished essay, Writings, FCP/NYPL.

33. FC to MC, letter dated 19 November 1923, Correspondence, FCP/NYPL.

34. FC to SG, letter dated 1 December 1923, Correspondence, FCP/NYPL. Wolfson's thesis was published in 1926 and she became a professor of economics at Brooklyn College in 1928, where she taught till her retirement in 1967. See Wolfson (1926).

35 . FC to 'dear friend', letter dated 28 July 1937, Correspondence, FCP/NYPL.

36.

\section{Archival sources}

Fannia M. Cohn papers. Manuscripts and Archives Division. The New York Public Library. Astor, Lenox, and Tilden Foundations.

Rose Schneiderman papers. The Archives of the Tamiment Library, Collection TAM/18.

Archival sources

\section{References}

Altman, J. (1982). Epistolarity: Approaches to a form. Columbus, OH: Ohio State University Press. Arendt, H. (1963-1990). On revolution. London: Penguin.

Arendt, H. (1994). Understanding and politics. In J. Kohn (Ed.), Essays in understanding 19301954: Formation, exile and totalitarianism (pp. 307-327). New York, NY: Schocken Books.

Arendt, H. (1998). The human condition. Chicago, IL: University of Chicago Press.

Barton, D., \& Hall, N. (Eds.). (2000). Letter writing as a social practice. Amsterdam: John Benjamins.

Butler, J. (2005). Giving an account of oneself. New York, NY: Fordham University Press.

Cavarero, A. (2000). Relating narratives: Storytelling and selfhood. (P. Kottman, Trans.). London: Routledge.

Cohen, R. C. M. (1976). Fannia Cohn and the International Ladies' Garment Workers' Union (Ph. D. thesis). Los Angeles, CA: University of Southern California.

Ellen, N. (1983). Charles A. Beard: An intellectual biography. Carbondale: Southern Illinois University Press.

Foucault, M. (1988). Technologies of the self. In M. H. Luther, H. Gutman, \& P. H. Hutton (Eds.), Technologies of the self (pp. 16-49). London: Tavistock.

Gillmore, L. (1994). Autobiographics: A feminist theory of women's self-representation. Ithaca, NY: Cornell University Press.

Guaraldo, O. (2001). Storylines: Politics, history and narrative from an Arendtian perspective. Jyväskyla: SoPhi. 
Guaraldo, O. (2012). Thinkers that matter: On the thought of Judith Butler and Adriana Cavarero. About Gender. International Journal of Gender Studies, 1, 92-117.

Howlett, C. F. (1993). Brookwood labor college and the struggle for peace and social justice in America. Lewiston, NY: Edwin Mellen Press.

Hyvärinen, M., Hydén, L. C., Saarenheimo, M., \& Tamboukou, M. (Eds.). (2010). Beyond narrative Coherence. Amsterdam: John Benjamins Publishing.

Jolly, M. (2008). In love and struggle: Letters in contemporary feminism. New York, NY: Columbia University Press.

Kristeva, J. (2001). Life is a narrative. (F. Collins, Trans.). Toronto: University of Toronto Press.

Ricoeur, P. (1981). Narrative time. In W. J. T. Mitchell (Ed.), On narrative (pp. 165-186). Chicago and London: The University of Chicago Press.

Stein, L. (1962). The Triangle Fire. Ithaca, NY: Cornell University Press.

Tamboukou, M. (2011). Interfaces in narrative research: Letters as technologies of the self and as traces of social forces. Qualitative Research, 11, 625-641.

Tamboukou, M. (2013). Educating the seamstress: Studying and writing the memory of work. History of Education, 42, 509-527.

Tamboukou, M. (2014a). The female self as punctum: Fannia Cohn's archival technologies of the self. BSA Auto/biography Yearbook. Vol. VII, 99-113.

Tamboukou, M. (2014b). 'Not everything that the bourgeois world created is bad': Aesthetics and politics in women workers' education. Discourse: Studies in the Cultural Politics of Education. [Online]. http://dx.doi.org/10.1080/01596306.2014.904103

Weissberg, L. (2000). Introduction: Hannah Arendt, Rahel Varnhagen and the Writing of (Auto) biography. In L. Weissberg (Ed.), Rahel Varnhagen: The Life of a Jewess (pp. 3-69) (R. Winston \& C. Winston, Trans.) Baltimore, MD: The Johns Hopkins University Press.

Wolfson, T. (1926). The woman worker and the trade unions (PhD dissertation). Washington, DC: Brookings Institution.

Wolin, S. (1977). Hannah Arendt and the ordinance of time. Social Research, 44, 91-105. 